\title{
Críticos e historiadores da literatura: pesquisando a identidade nacional
}

Regina Zilberman* 
Entre 1829 e 1831, o Cônego J anuário da Cunha B arbosa apresentou ao público carioca, em impressão da Tipografia Nacional, que ele mesmo dirigia, o Parnaso Brasilei ro, organizado sob a forma de cadernos que, colecionados, vieram a formar primeira seleção de poesia nacional produzida no que, na época, era um país recentemente emancipado. Os modelos ad otados pelo diligente religioso fluminense provinham provavelmente da E uropa, pois na abertura ele se refere “(a)os que se deram a uma semelhante tarefa na Inglaterra, França, Portugal, e Espanha" ${ }^{\text {; }}$ com maior convicção, pode-se supor que tinha em mente o Parnaso Lusitano, de A Imeida G arrett, lançado em Paris, em 1826, obra cujo impacto sobre os intelectuais de nosso país estendeu-se até meados da década de 70 do século XIX.

Não é injusto pensar que Cunha Barbosa inaugurou os estudos literários no Brasil. Antes dele, seu professor de Retórica, o escritor Silva Alvarenga, tinha produzido versos em que veiculava a poética por ele considerada superior, assim como expunha sua admiração por B asílio da G ama, autor de O Uraguai e exemplo acabado dos valores literários prezados a seu tempo. Silva Alvarenga detém, portanto, a posição de pioneiro, podendo ser considerado o mentor do Cônego J anuário; mas foi o Parnaso Brasileiro que, entre os contemporâneos e alguns pósteros, funcionou como parâmetro para o conhecimento da poesia nacional elaborada até então.

J anuário da Cunha Barbosa, contudo, não se alinhou à estética romântica. Autor de um poema com pretensões épicas, Niterói , e de numerosas paródias (uma delas, a peça A Rusga da Praia Grande, ou O Quixotismo do General das Massas, ataca o General Abreu e Lima, este igualmente crítico das Letras brasileiras no

1 BARBOSA, J anuário da Cunha. Parnaso brasileiro. Rio de J aneiro: Tipografia Imperial e Nacional, 1829. 
Bosquejo Histórico, Político e Literário do Brasil, de 1835), o Cônego enquadra-se ao conjunto de epígonos do Neoclassicismo que, em algumas de nossas histórias da literatura figura como Pré-R omantismo. O romantismo brasileiro nasceu em outras plagas: Domingos J osé G onçalves de Magalhães, M anuel de Araújo Porto Alegre e F rancisco de Sales Torres Homem foram-no encontrar às margens do Sena, como sugere a carta enviada pelo primeiro, em 20 de janeiro de 1834, a M onte Alverne:

Os poetas estão aqui empenhados em explorar a mina da meia-idade, fatigados com as idéias antigas, e não podendo quase marchar na estrada de Racine e Corneille e Voltaire, eles calcam todas as leis da unidade tão recomendadas pelos antigos; as novas tragédias não têm lugar fixo, nem tempo marcado, podem durar um ano e mais; o caráter dessas composições é muitas vezes horrível, pavoroso, feroz, melancólico, frenético e religioso. [...] Os principais trágicos são De Laragotine, Alexandre Dumas, Victor Hugo. Esses poetas chamam-se românticos; eu tenho visto representar as principais dessas peças. ${ }^{2}$

De posse da nova visão da arte e da história, eles reavaliam a literatura e as artes deixadas ao partir do Brasil, para então formular os princípios de uma nova poética para a nação que conquistara a autonomia política há pouco. O resultado, a que se associa outro estudante brasileiro na época residindo em Paris, J oão Manuel Pereira da Silva, gera, além dos versos de Suspiros Poéti cos e Saudades, que $\mathrm{G}$ onçalves de Magalhães edita em 1836, os dois números da revista Niterói, lançados no mesmo ano na $\mathrm{F}$ rança e certamente exportados para o B rasil, no bojo da estética que reivindicava.

Esse fato torna-os pioneiros da crítica literária romântica, o que não obscurece o papel de J anuário da Cunha B arbosa - até se poderia pensar que o nome do periódico dirigido por G onçalves de Magalhães, Araújo Porto A legre e Torres Homem homenageia o Cônego, reproduzind o o título de sua principal obra - e sim define o campo em que cada um atuou. O grupo Niterói , literariamente educado na E uropa, alinhava-se aos modernos; logo, aponta para o novo, discutindo não apenas que encaminhamento deveria ter, mas principalmente estimando e pesando a contribuição (ou a falta) da herança portuguesa. Se a ele juntarem-se os editores da Revista da Soci edade Filomática, de São Paulo, entre os quais se destacam J . Salomé Queiroga e o futuro jornalista J ustiniano J osé da R ocha, que igualmente atuaram na década de 30 do século XIX , constatar-se-á que a crítica literária brasileira nasce nesse período sob a égide da estética romântica, preocupada, no caso de nosso país, com a questão relativa à identidade nacional da literatura aqui produzida.

PORTO ALEGRE - GONÇALVES DE MAGALHÃES. Cartas a Monte Alverne. São Paulo: Conselho Estadual de Cultura, 1964. p. 16-7. 


\section{I dentidade nacional}

Podem-se considerar exemplares da crítica romântica o seguinte grupo de obras, aqui arroladas cronologicamente: Ferdinand Denis, Résumé de I'Histoire Littéraire du Brésil (1826) ; Almeida Garrett, “B osquejo da H istória da Poesia e Língua Portuguesa" ( 1826) ; J anuário da Cunha B arbosa, Parnaso Brasi lei ro (1829-1831); General J osé I nácio de Abreu e Lima, Bosquejo Históri co, Político e Literário do Brasil (1835); G onçalves de Magalhães, “Ensaio sobre a História da Literatura do Brasil" (1836); Pereira da Silva, "E studos sobre a Literatura" (1836); J oaquim Norberto de Sousa Silva, "B osquejo da História da Poesia B rasileira" (1841); Pereira da Silva, "U ma Introdução H istórica e Biográfica sobre a Literatura B rasileira" (1843) Santiago Nunes R ibeiro, “Da N acionalidade da Literatura B rasileira"( 1843); J oaquim Norberto de Sousa e Silva, "Considerações G erais sobre a Literatura Brasileira" ( 1843) ; J oaquim Norberto de Sousa e Silva e E mílio A dêt, "I ntrodução sobre a L iteratura Nacional" ( 1844); Álvares de Azevedo, Literatura e Ci vilização em Portugal (1849-1850); Francisco Adolfo de Varnhagen, “Ensaio Histórico sobre as Letras no B rasil" (1850); J oaquim N orberto de Sousa Silva, "A Língua B rasileira"( 1855); Machado de Assis, "O Passado, o Presente e o Futuro da L iteratura"(1858); M acedo Soares, Harmoni as brasileiras (1859); M acedo Soares, “E nsaios de Análise Literária. Bittencourt Sampaio: Flores Silvestres"(1860); M acedo Soares, “Tipos Literários Contemporâneos: Gonçalves Dias"( 1861); Quintino Bocaiúva, Lírica naci onal (1862); Adadus Calpe (pseudônimo de Antônio Deodoro de Pascual), "Estudo sobre a Nacionalidade da Literatura"(1862); Fernandes Pinheiro, Meandro Poético (1864); J osé de Alencar, "Bênção Paterna"(1872); Machado de Assis, "Notícia da Atual Literatura B rasileira"( 1873); “Literatura B rasileira”, projeto de investigação que J osé de A lencar deixou sem realizar, publicado postumamente no quarto volume da Obra Completa desse escritor, datada de 1960. Nem todos os textos foram escritos por brasileiros, e alguns deles publicaram-se no Exterior, circularam, contudo, preferencialmente no Brasil, entre o final dos anos 20 e a década de 70 do século XIX, constituindo o corpo de idéias que ajudou os intelectuais a pensarem, julgarem e criarem o que passava por ficção e poesia no país.

Considerado esse conjunto, verifica-se que o sintagma identidade nacional com que se pensa o período, não aparece nos textos, tratando-se provavelmente de uma construção posterior. M esmo o substantivo identidade é raramente empregado. Nesse intervalo, ele aparece apenas em três ensaios publicados e um inédito, com o significado de semel hança.

O primeiro a utilizar o termo é Santiago Nunes R ibeiro, em “Da Nacionalidade da Literatura B rasileira", colocado no primeiro volume da Minerva Brasiliense, em 1843, que se vale da palavra em duas oportunidades. Nos parágrafos iniciais, comenta: 
Dos estudos fenomênicos a física moderna se eleva ao espiritualíssimo que tudo explica por forças e por leis, e desta esfera se abalança a outra mais sublime em que pretende achar a identidade das forças da natureza e das do espírito. Ora esta identidade absoluta é Deus. ${ }^{3}$

Mais adiante, ele observa, ao discutir a tese de seu trabalho, a saber, a constatação da nacionalidade da literatura escrita no B rasil:

Duas são as causas principais que deviam dar à poesia brasileira o caráter e feições da portuguesa - a identidade dos estudos e a da língua dos dois países.

A primeira citação indica de imediato o sentido do termo: equivale à igualdade, conforme a qual dois objetos podem coincidir; a segunda, o vocábulo se aplica à situação dos estudos sobre a brasilidade da literatura nacional, que se distingue da portuguesa, por estar ausente a identidade entre elas.

Francisco Adolfo de Varnhagen no "Ensaio Histórico sobre as L etras no B rasil", que precede o Florilégi o da Poesia Brasileira, redigido ao final da década de 40 do século $X I X$, também se vale do vocábulo enquanto igualdade, quando compara as línguas faladas no Brasil e em Portugal, tema que atraiu o interesse dos intelectuais românticos, pois as diferenças lingüísticas apontariam para a especificidade das respectivas literaturas; o historiador pergunta: “É , por ventura, tão verdadeira, tão estrita essa identidade da língua?"4

Macedo Soares, em ensaio sobre a poesia de Gonçalves Dias, publicado em 1861, na Revista Mensal do Ensi no Fi losófi co Paulistano, recorre ao vocábulo numa única oportunidade, lembrando que "[d]a identidade da concepção do artista" decorre "o pensamento da obra" ${ }^{5}$, logo, não fugindo à percepção de que o vocábulo refere-se à uniformidade. Por sua vez, J osé de Alencar, no projeto de escrita de uma história da literatura brasileira, documento que permaneceu inédito e foi incluído na Obra Completa pelos organizadores, refere-se à identidade de raça ${ }^{6}$, destacando, contudo, que "o solo, o clima, e a natureza é outro".

Os autores do século XIX que viveram sob a égide do pensamento romântico não compreenderam identidade como diferença, e sim como similaridade, e talvez fosse do que eles quisessem se libertar.

3 RIBEIRO, Santiago Nunes. "Da Nacionalidade da Literatura Brasileira". Minerva Brasiliense, J ornal de Ciências, Letras e Artes. n. 1, v. 1, 1o de novembro de 1843.

4 VARNHAGEN, Francisco Adolfo de. “Ensaio Histórico sobre as Letras no Brasil”. In: ZILBERMAN, R egina e MOREIRA, Maria E unice. O Berço do Cânone. Porto Alegre: M ercado A berto, 1998. p. 85. Originalmente publicado em Florilégio da Poesia Brasileira. Lisboa: Laemmert, 1850. v. 1.

5 SOARES, Antônio J oaquim de Macedo. "Tipos Literários Contemporâneos: Gonçalves Dias". In: CASTELLO, J osé Aderaldo. Textos que interessam à História do Romantismo. São Paulo: Conselho Estadual de Cultura, 1963. v. II. Originalmente publicado em Revista Mensal do Ensaio Filosófico Paulistano, n. 5, agosto de 1860, p. 65-72.

$6 \quad$ ALENCAR, J osé de. "Literatura B rasileira”. In: Obra Completa. v. IV. Rio de J aneiro: Aguilar, 1960. 
Nacional, por outro lado, é adjetivo que freqüenta com assiduidade esses autores, bem como a maior parte dos críticos que fizeram prosperar a historiografia da literatura brasileira. Nem todos tinham nascido no país ou aqui viviam; mas nenhum deles deixou de mencionar a palavra-chave que ocupava seus corações e mentes, sinal de confirmação da natureza de nossa literatura.

O francês Ferdinand Denis escreveu provavelmente a primeira história da literatura brasileira, porque as referências a autores nascidos ou que viveram no país apareciam até então embutidos na análise da literatura portuguesa como um todo, como ocorre em Diogo B arbosa Machado, autor da Bi bli oteca Lusi tana (17411759), Friedrich Bouterwek, na Geschichte der Portugiesiscgen Poesie und Beredsamkeit (1805) e Simonde de Sismondi, em De la Littérature du Midi de I'E urope. O Resumo da História Literária do Brasil, ainda que apêndice do Resumo da História Literária de Portugal, dedica-se integralmente aos intelectuais e poetas que produziram suas obras na América, colaborando para a criação de um cânone próprio à literatura da nação que, em 1826, acabava de se separar politicamente de Portugal e buscava delimitar seu espaço literário.

Em Denis, o nacional ascende à condição de critério, como se verifica no trecho em que examina o Caramuru, de Santa R ita Durão:

Não obstante, julguei-me obrigado a analisar a obra de Durão, porque reveste caráter nacional, apesar de suas imperfeições, e assinala claramente o objetivo a que deve dirigir a poesia americana ${ }^{7}$.

Evidenciar caráter nacional é o mérito do poema de D urão, tão significativo, que se apresenta igualmente como meta mais geral a ser alcançada pela poesia americana. O caráter nacional é mencionado mais adiante, não mais como presença, mas na situação de falta, pois Denis deplora sua ausência, quando estuda, por exemplo, a comédia:

Nesse belo país, que se crê ainda obrigado a pedir por empréstimo à E uropa a maior parte de seus usos, freqüentemente se nota que a comédia não tem muito caráter nacional, e que os costumes do mundo antigo são ali evocados de maneira tão extravagante que deixam de ser exatos. ${ }^{8}$

Caráter nacional talvez possa ser considerado o equivalente à identidade nacional; mas o adjetivo apresenta matizes variados, porque aparece ainda em outras circunstâncias. Assim, quando Denis refere-se a G onzaga, poeta condena-

DE NIS, Ferdinand. Resumo da História Literária do Brasi I. Trad. Guilhermino César. Porto Alegre: Lima, 1968. p. 62. Idem, p. 85. 
do por não ter explorado suficientemente as sugestões oferecidas pela natureza e o ambiente vivenciado pelo autor, o que impede a afirmação da cor local em seus versos, ele precisa sustentar a nacionalidade do poeta em outro fator, no caso da popularidade de seus versos, conhecidos e declamados por todos:

Seja como for, Gonzaga é um poeta nacional; reproduzidos por toda a parte, seus cantos enchem de vida as solidões mais remotas do B rasil. ${ }^{9}$

A palavra nacional não é, contudo, recorrente no ensaio de Ferdinand Denis, restringindo-se a essas poucas ocasiões. O mesmo não vale para o ensaio de Almeida G arrett, "B osquejo da H istória e da Poesia Portuguesa”, que seguidamente emprega a expressão para discordar dos rumos da poesia do passado e da atualidade.

O "Bosquejo" data de 1826, ano também do estudo de Denis; à diferença deste, porém, examina, num único bloco, autores nascidos em Portugal e no B rasil, embora reconheça a diferente procedência de uns e outros. Mas, a ambos os casos, expõe as mesmas exigências, sendo o nacional o divisor de águas.

$O$ adjetivo aparece em, pelo menos, cinco situações distintas: por três vezes acompanha o substantivo "poesia", equivalendo em princípio à literatura portuguesa em versos. É o que sugere a primeira vez em que o sintagma aparece, quando Almeida G arrett critica o renascentista Antônio Ferreira por imitar os antigos, prática que compromete por inteiro a literatura:

Cegou-se todavia o nosso bom Ferreira na imitação dos antigos; copiou-os, não os imitou: e daí, enriquecendo a língua, empobreceu a literatura, porque a avezou a esse hábito de copista; cancro que rói o espírito criador, alma e vida da poesia nacional. ${ }^{10}$

Garrett distingue a imitação, que valoriza e prefere, da cópia, prática que desnacionaliza a poesia, tornando-a servil a uma literatura estrangeira. Contudo, para ele reconhecer seu caráter nacional é preciso haver coincidência entre o lugar designado por esse tipo de adjetivo e o nativismo dos temas apresentados. Temas locais e pátrios costumes transferem-se para as obras, conferindo-Ihes espírito próprio, cuja presença garante a nacionalidade da literatura. A relação entre esses elementos aparece na consideração em que $G$ arrett exemplifica seu raciocínio, apelando para o processo, experimentado pela literatura latina, de adaptação da arte grega a seus desígnios particulares:

Idem, p. 79.

GARRETT, J oão B atista Leitão de AImeida. “B osquejo da História da Poesia e Língua Portuguesa”. In: ZILBER M AN, R egina e MOREIRA, Maria E unice. Op. cit., p. 38. Originalmente publicado em Parnaso Lusitano. Paris: J. P. Aillaud, 1826. v. 1. 
Essa casta de obras estuda-se, imita-se, não se traduz. Quem assim faz acomoda-as ao caráter nacional, dá-Ihes cor de próprias, e não só veste um corpo estrangeiro de alfaias nacionais (como o tradutor), mas a esse corpo dá feições, gestos, modo, e índole nacional: assim fizeram os latinos, que sempre imitaram os gregos e nunca os traduziram; assim fizeram os nossos poetas da boa idade. ${ }^{11}$

A observação é digna de nota, porque G arrett não está reivindicando a mudança do gênero ou do estilo; para ele, nacionalidade da literatura não implica originalidade, relação cara a vários românticos. O escritor português aceita a imitação, que diferencia da cópia, porque a primeira é criadora, e a segunda, reprodutora, neutralizando a possibilidade de adaptar a literatura às condições singulares de uma certa região.

O transplante pela imitação é legítimo, porque a índole naci onal se introduz no texto; em outros momentos do ensaio, a expressão espírito naci onal dá conta do que $\mathrm{G}$ arrett tem em mente: cada área geográfica dispõe de personalidade, que poderá transparecer na obra poética. Essa noção aparece, pela primeira vez, fora do contexto artístico, quando o crítico refere-se à ação de $D$. M anuel, cujo reinado foi extremamente benéfico ao país, já que "tudo foi crescer em Portugal; artes, ciências, comércio, riqueza, virtudes, espírito nacional". ${ }^{12}$

O espírito nacional emana da pátria, cujo poderio e expressividade ficam sintetizados naquele. Por isso, quando a autonomia política se perde, ele fenece, atingindo todas as manifestações, de que a poesia forma uma parte. O trecho a seguir esclarece o modo como os românticos entenderam as ligações entre nacionalismo e poesia:

Tínhamos perdido a independência; perdemos logo o espírito nacional, o timbre, o amor pátrio (que amor da pátria poderá haver em quem pátria já não tem); a lisonja servil, a adulação infame levou nossos desonrados avós a desprezar seu próprio riquíssimo e tão suave idioma, para escrever no gutural castelhano, preferindo os sonoros helenismos do português às aspiradas aravias da língua dos tiranos. Vergonha que só tem par nas derradeiras vergonhas com que nos enxovalharam a língua e a fama os tarelos, francelhos, galiciparias e toda a caterva dos galômanos. ${ }^{13}$

Garrett refere-se aqui à literatura portuguesa do século XVII, quando seu país tornou-se membro do império espanhol, sob o domínio dos Felipes. Destitu-

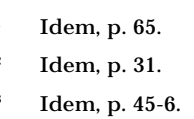


ído de autonomia política, Portugal se deixou dominar também intelectualmente: abriu mão do idioma, redigindo a poesia em castelhano, mais tarde cedendo à influência francesa, igualmente desprezada pelo crítico.

O espí ri to naci onal depende da quantidade de a mor pátrio, que transparece na linguagem poética que o traduz. I gnorar a própria nação gera uma literatura servil, de espinha quebrada, submissa aos cânones estrangeiros e estranhos ao mundo de onde ela provém. Essa acusação, que G arrett dirige a seus conterrâneos, estende-se aos autores nascidos no B rasil.

Assim, embora o "Bosquejo", ao contrário do Resumo, de Ferdinand Denis, não se restrinja à literatura escrita por brasileiros, ele faz advertências que geraram reações profundas nos poetas do na época recentemente criado país americano. As observações suscitadas pelas "produções dos engenhos brasileiros" põem o dedo na ferida, pois, ainda que reconheça que elas vêm enriquecendo a literatura portuguesa, Garrett denuncia a principal lacuna: “a educação européia apagou-Ihes o espírito nacional"; em outras palavras, "parece que receiam de se mostrar americanos; e daí lhes vem uma afetação e impropriedade que dá quebra em suas melhores qualidades". O que o conduz a essa conclusão, ao mesmo tempo tão segura e tão indesejável? O fato de em suas obras faltarem "as majestosas e novas cenas da natureza naquela vasta região"; a mera presença delas teria conferido "a seus poetas mais originalidade, mais diferentes imagens, expressões e estilo, do que neles aparece". ${ }^{14}$

Nas páginas iniciais de D. Casmurro, B entinho, o narrador do romance, explica por que a morada que construiu na velhice à imagem e semelhança da casa de sua adolescência não o satisfazia: "falto eu mesmo, e esta lacuna é tudo". ${ }^{15}$ À falta similar refere-se AImeida G arrett: a exploração das cenas sugeridas pela natureza, majestosa e nova conforme o estudioso português, teria resolvido o impasse dos românticos brasileiros, conferindo às suas obras a originalidade tão almejada, logo, expressando a ambicionada nacionalidade.

E is que então se associam nacionalidade e originalidade: não é a recusa da imitação que a impede, e sim a ausência de um olhar para fora, para o mundo em que o poeta vive, capacitando-o a introduzi-lo no texto literário. G arrett expressa essa relação não a propósito da poesia brasileira, e sim quando discute a lírica portuguesa renascentista, que aceitou sem discutir regras que a levavam a introduzir em seus versos imagens e mitos importados da Antigüidade clássica. Essa opção custou caro, ao comprometer a originalidade e, por extensão, a nacionalidade das obras então escritas:

\footnotetext{
Idem, p. 56.

15 ASSIS, Machado de. Dom Casmurro. São Paulo: Mérito, 1959. p. 8.
} 
Claro é que a história, a oratória, todas as artes do discurso deviam de florescer com tal aumento. Com elas todas medrou e cresceu a poesia na delicadeza, na harmonia, no gosto; porém desmereceu muito, demasiado na originalidade, no caráter próprio, que perdeu quase todo, na nacionalidade, que mui pouco se the ia. Todos os deuses gregros tomaram posse do maravilhoso poético, todas as imagens, todas as idéias; todas as alusões do tempo de Augusto ocuparam as mais partes da poesia; e mui pouco ficou para o que era nacional, para o que já tínhamos, para o que podíamos adquirir ainda, para o que naturalmente devia nascer de nossos usos, de nossas recordações, de nossa arqueologia, do aspecto de nosso país, de nossas crenças populares, e enfim de nossa religião. ${ }^{16}$

Da atenção dirigida à exterioridade que cerca o escritor emerge o nacional, por extensão, o original, por fim, a excelência. É por ser nacional que homens se destacam, e A Imeida G arrett não se restringe à literatura. E logia, por exemplo, D . J oão I, que, por ter dado "ao idioma pátrio valente impulso, mandando usar dele em todos os atos e instrumentos públicos, que até então se faziam em latim" foi "o mais nacional de todos os nossos reis"17. P ela mesma razão, B asílio da Gama constituiu, dentre os brasileiros, seu poeta preferido:

J usto elogio merece o sensível cantor da infeliz Lindóia que mais nacional foi que nenhum de seus compatriotas brasileiros. O U raguai deJ osé B asílio da Gama é o moderno poema que mais mérito tem na minha opinião. Cenas naturais mui bem pintadas, de grande e bela execução descritiva; frase pura e sem afetação, versos naturais sem ser prosaicos, e quando cumpre sublimes sem ser guindados; não são qualidades comuns. Os brasileiros principalmente lhe devem a melhor coroa de sua poesia, que nele é verdadeiramente nacional, e legítima americana. ${ }^{18}$

A expressão das peculiaridades locais nacionaliza a literatura, configurando sua identidade; ao mesmo tempo, garante a originalidade e a diferença, de modo que identidade advém não da semelhança, e sim da alteridade, aquela que o poeta manifesta, quando dá conta do universo que o rodeia. Os brasileiros, por efeito da educação, podem não ter conseguido realizar esse intento, mas Garrett Ihes oferece a pista que os levará à sua concretização: cultivar o espírito nacional, o que, nas suas e nas palavras de Denis, determinam o caráter, e desse talvez advenha a desejada identidade, produto da originalidade e efeito da qualidade.

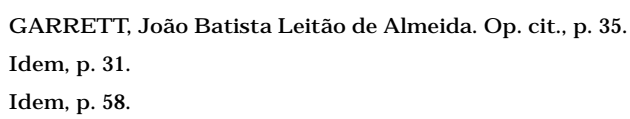


O primeiro brasileiro a tratar do assunto deve ter sido G onçalves de MagaIhães, quando, recebido pelos membros do Instituto Histórico de Paris, em 1834, anunciou o teor da história da literatura que vinha redigindo. Seus pares na ocasião, A raújo Porto Alegre e F rancisco de Sales Torres Homem, igualmente se manifestaram sobre as artes, a ciência e a literatura produzida no solo pátrio ${ }^{19}$, mas foi o poeta que deu a versão final às idéias do grupo no "E nsaio sobre a História da Literatura do Brasil" publicado em 1836. Em 1865, Gonçalves de Magalhães reeditou, com alterações, o estudo, incluindo-o nos Opúsculos Históricos e Literários, lançados pela Garnier. As modificações são significativas, porque a única menção feita ao caráter nacional ocorre na segunda versão do texto, quando o autor substitui a frase

Aqui terminaremos a vista geral sobre a história da literatura do B rasil, desta literatura não no país nascida20

Por:

Aqui terminaremos a vista geral sobre a história da literatura do B rasil, dessa literatura sem um caráter nacional pronunciado, que a distinga da portuguesa. ${ }^{21}$

Na versão original, preocupava a Magalhães a naturalidade da literatura; em 1865, ele mostra que, isoladamente, a naturalidade não satisfazia, era preciso que emergisse o caráter nacional. O pera-se uma disjunção: há, de um lado, a literatura do Brasil, de outro, o caráter nacional, ausente naquela, impedindo distingui-la de sua co-irmã portuguesa. Não basta, pois, que a literatura tenha nascido e prosperado num certo solo; cumpre também que ela englobe uma qualidade peculiar, que a torne distintiva e singular. No caso do B rasil, conforme M agalhães, isso não aconteceu, e o "Ensaio" resume o esforço do autor em buscar as causas do problema. Situa-as principalmente no processo de colonização imposto por Portugal à colônia americana, que fez com que os nascidos na A mérica não quisessem assumir a naturalidade dentro da qual nasceram. Escreve o poeta desde Paris, referindo-se à época em que Portugal ocupava o território que Ihe competira no Novo M undo:

19 Os textos apresentados por Magalhães, Porto Alegre e Torres Homem em Paris estão registrados em: ZILBER M AN Regina e MOREIRA, Maria E unice (org.) Crítica literária romântica no B rasil: primeiras manifestações. Cadernos do Centro de Pesquisas Literárias da PUCRS. v. 5, n. 2, ago. 1999.

20 MAGALHÃES, Domingos J osé Gonçalves de. "Ensaio sobre a história da Literatura do Brasil". Estudo preliminar. Niterói - Revista Brasiliense. Paris: Dauvin et Fontaine, Libraires, 1836. p. 153. E dição facsimilada patrocinada pela Academia Paulista de Letras, em 1978.

21 Idem. "Discurso sobre a História da Literatura do Brasil". In: Opúsculos Históricos e Literários. 2 ed. Rio de J aneiro: G arnier, 1865 
Triste é sem dúvida a recordação dessa época, em que o brasileiro, como lançado em terra estrangeira, duvidoso em seu próprio país vagava, sem que dizer pudesse: isso é meu, neste lugar nasci! Envergonhava-se de ser brasileiro, e muitas vezes com o nome português se acobertava, para ao menos aparecer como um ente da espécie humana, e poder alcançar um emprego no seu país. Destarte, circunscrito em tão curto estádio, estranho à nacionalidade, sem o incentivo da glória, este novo povo vegetava.22

O fragmento parece responder a uma afirmação de G arrett antes citada, em que o português sugere, a propósito dos poetas nascidos no Brasil, que "a educação européia apagou-Ihes o espírito nacional". No entendimento de Magalhães, a repressão portuguesa, durante a colonização, sufocou o "espírito nacional", gerando literatura de segunda mão. Eis por que ele procede à denúncia da falta de autenticidade da poesia produzida no Brasil, num trecho doravante paradigmático da visão do autor sobre a literatura do país:

A poesia do B rasil não é uma indígena civilizada, é uma grega, vestida à francesa, e à portuguesa, e climatizada no B rasil; é uma virgem do Helicon, que, peregrinando pelo mundo, estragara seu manto, talhado pelas mãos de $\mathrm{Homero,} \mathrm{e}$ sentada à sombra das palmeiras da A mérica, se apraz ainda com as reminiscências da pátria, cuida ouvir o doce murmúrio da Castália, o trépido sussurro do Lodon e do Ismeno, e toma por um rouxinol o sabiá, que gorjeia entre os galhos da laranjeira. Encantados por esse nume sedutor, por essa bela estrangeira, os poetas brasileiros se deixaram levar por seus cânticos, e olvidaram as simples imagens, que uma natureza virgem com tanta profusão Ihes oferecia [...] Tão grande foi a influência, que sobre o gênio brasileiro exerceu a grega mitologia transportada pelos poetas portugueses, que muitas vezes poetas brasileiros em pastores se metamorfoseiam, e vão apascentar seu rebanho nas margens do Tejo, e cantar à sombra das faias. ${ }^{23}$

Não há como não reconhecer aí alguns dos ícones mais caros ao Romantismo brasileiro: "a indígena civilizada", "a sombra das palmeiras da América", "o sabiá que gorjeia entre os galhos da laranjeira". Essas alegorias já haviam figurado em parte no "B osquejo" de AImeida Garrett, que condenara G onzaga por não ter feito sua amada Marília,

como a Virgínia de Saint-Pierre, sentar-se à sombra das palmeiras, e enquanto lhe revoavam em torno o cardeal soberbo com a púrpura dos reis, o sabiá terno e melodioso, [...] ela se entretivesse em tecer para o seu amigo e seu cantor uma

\footnotetext{
22 Idem, "Ensaio sobre a História da Literatura do Brasil", ed. cit., p. 141

23 Idem, p. 146-7.
} 
grinalda não de rosas, não de jasmins, porém dos roxos martírios, das alvas flores dos vermelhos bagos do lustroso cafezeiro. ${ }^{24}$

Magalhães, de novo, parece estar respondendo ao crítico lusitano, atribuindo a falta mais uma vez à perniciosa influência dos vates portugueses, que igualmente se deixaram atrair pela Musa clássica.

A nacionalização da poesia aparece para Magalhães na condição de um programa a ser executado, reconhecendo indiretamente que os detratores europeus, G arrett e Denis, por exemplo, tinham razão. Discorda quando se trata de verificar as causas, mas, também para ele, o desajuste entre o gentílico - brasileiro - que acompanha os substantivos poesia ou literatura, e o adjetivo nacional é o problema por excelência a ser enfrentado pelos autores nascidos no país a que pertencia.

Criar a poesia nacional transformou-se na tarefa de sua geração, que, conforme membros do grupo a que se ligou, o próprio Magalhães satisfez. Pelo menos, é o que se lê já em 1836, ano do lançamento de Suspiros Poéticos e Saudades, nos "E studos sobre a Literatura", que J. M. Pereira da Silva colocou no segundo volume de Niterói:

É com o maior prazer, que vimos impressos os Suspiros Poéticos e as Saudades, do nosso patrício Magalhães; uma coleção de odes e cantatas, escritas segundo a inspiração, onde o patriotismo, a doçura de uma alma cândida, e a poesia se disputam a primazia; este livro é um monumento de glória erigido ao B rasil, um monumento verdadeiramente nacional e poético $[\ldots]^{25}$

Similar reconhecimento aparece no "Bosquejo da História da Poesia B rasileira", de J oaquim Norberto de Sousa Silva, que, em 1841, instala o confrade G onçalves de Magalhães na posição de chefe da escola romântica brasileira, lugar que, mesmo atualmente, a historiografia da literatura brasileira não contesta. Segundo Norberto, o autor dos Suspiros Poéti cos e Saudades "ergueu o estandarte da reforma, pôs-se à frente da mocidade e uma nova época começou para a poesia brasileira". ${ }^{26}$

Para Pereira da Silva, não era preciso conferir nacionalidade à produção literária anterior ao aparecimento de Magalhães e/ou da geração a que ele mesmo pertencia. E m “Uma I ntrodução H istórica e B iográfica sobre a L iteratura B rasileira”, que precede o Parnaso Brasileiro, de 1843, é freqüente a acusação de falta de nacionalismo nos poetas do século XVIII, ecoando as afirmações de Almeida G arrett eFerdinand Denis:

24 GARRETT, J oão Batista Leitão de Almeida. Op. cit., p. 57-8.

25 SILVA, J oão M anuel Pereira da. "Estudos sobre a Literatura”. Niterói-Revista Brasiliense. Paris: Dauvin et Fontaine, Libraires, 1836. v. 2. p. 239. E dição facsimilada patrocinada pela Academia Paulista de Letras, em 1978.

$26 \quad$ Idem, ed. de 1998, p. 137. 
A literatura brasileira do século XVIII, seguindo as mesmas pisadas das literaturas dos diversos estados da E uropa, máxime da portuguesa, nada tem de nacional, senão o nome de seus escritores, e o acaso de haverem no B rasil nascido. É fado que até este século que ora decorre, havendo o B rasil produzido tantos e tão grandes gênios, a todos ou a quase todos se possa imputar o defeito de imitarem muito os escritores europeus, e de se não entregarem ao vôo livre de sua romanesca imaginação. ${ }^{27}$

A situação, contudo, deixava a literatura brasileira numa situação paradoxal: ela dispunha doravante de caráter nacional, mas ficava de mãos vazias, sem passado, numa época em que possuir história e ancestrais era sintoma de existir. Por isso, a solução de Pereira da Silva ainda não servia; o ensaio de Santiago N unes Ribeiro, destinado a comprovar a "nacionalidade da literatura brasileira" tenta resolver o impasse.

O estudo aparece no primeiro volume da Minerva Brasi li ense, periódico que, entre 1843 e 1845, contou, entre os redatores, com a intelectualidade carioca da década de 40: Araújo Porto Alegre, E mílio Adêt, Francisco Torres Homem, Gonçalves de Magalhães, J anuário da Cunha Barbosa, J oaquim Norberto, Odorico Mendes, Santiago Nunes R ibeiro e Teixeira e Sousa. Ensaio de abertura de uma publicação que começava, ele não fica longe de um manifesto, introduzindo nos primeiros parágrafos a interrogação para a qual busca uma resposta:

O Brasil tem uma literatura própria e nacional, ou as produções dos autores brasileiros pertencem à literatura portuguesa, já em virtude dos vínculos que uniam ambos os países, já em conseqüência de serem escritas na língua lusi$\tan a ?^{28}$

A pergunta traz embutida alternativas que o autor deseja evitar, razão por que desenvolve o raciocínio a partir de duas refutações. A primeira atinge o $G$ eneral J osé Inácio de Abreu Lima, que, em 1835, publicou o polêmico Bosquejo Histórico, Político e Literário do Brasil, para acusar Portugal de não possuir, nem no presente, nem no passado, literatura, razão pela qual o Brasil igualmente carece de obras escritas merecedoras de atenção. Depois, contesta Gama e Silva, para quem a literatura brasileira integraria a portuguesa, por compartilharem, ambas, a mesma língua.

A Abreu Lima, R ibeiro descarta, afirmando que o conceito de literatura abraçado por ele era muito amplo, englobando ciência e cultura, de modo que não

$27 \quad$ Idem, ibidem, p. 169.

28 RIBEIRO, Santiago Nunes. Op. cit. 
enxergava a poesia como segmento à parte, digno de consideração específica. Contestar Gama e Silva, jornalista português radicado no começo da década de 40 no Rio de J aneiro, era mais difícil, tanto que a denúncia persistiu na consciência dos intelectuais brasileiros, que tentaram refutá-la, como revelam citações anteriores oriundas de Varnhagen e J osé de Alencar.

Santiago Nunes R ibeiro não nega que portugueses e brasileiros empreguem a mesma língua materna. O que rejeita é o "princípio incontestável de que a divisão das literaturas deva ser feita invariavelmente segundo as línguas em que se acham consignadas"; para ele, "outra divisão talvez mais filosófica seria a que atendesse ao espírito, que anima, à idéia que preside aos trabalhos intelectuais de um povo, isto é, de um sistema, de um centro, de um foco de vida social". O ensaísta discrimina o princípio de onde emana a separação entre literaturas produzidas por povos distintos, a saber:

as influências, do sentimento, das crenças, dos costumes e hábitos peculiares a um certo número de homens, que estão em certas e determinadas relações, que podem ser muito diferentes entre alguns povos, embora falem a mesma língua.

Santiago Nunes R ibeiro advoga um tipo de sociologia da literatura, afirmando que "as condições sociais e o clima do Novo Mundo necessariamente devem modificar as obras nele escritas nesta ou naquela língua da velha Europa". Integra-se às orientações do pensamento de seu tempo, ao aceitar que "causas naturais", destacado-se entre eles o ambiente, atuam sobre as "faculdades mais nobres" e os "produtos da inteligência". Seu mentor, no caso, é a "escola histórica de Hegel", em que apóia a tese relativa à pressão da atmosfera física sobre as produções do espírito, desde que matizada pela interferência da educação, a moral e sobretudo a religião, que "favoneiam o desenvolvimento legítimo das nossas faculdades, ou corpóreas ou anímicas". E sse desenvolvimento, contudo, será tanto melhor se contar com

os influxos salutíferos de um céu benigno, de uma terra fértil e pitoresca, abrilhantada e aquecida por um sol vivificante, refrigerada pelas virações suaves, por manhãs orvalhosas e nuvens que em pura chuva se desatam; de uma destas plagas admiráveis que falam à imaginação e ao sentimento, pela magnificência dos rios caudais e oceanos que as circundam, pelas correntes que as banham, pelo alcantilado de suas montanhas, pelas florestas misteriosas, por mil aspectos, enfim, belos, sublimes ou graciosos.

Graças a esse salto, Santiago chega onde quer, pois, no quesito clima, o Brasil apresenta situação privilegiada: 
E a que outro senão ao B rasil podem competir as grandiosidades e primores que em morte-cor pintamos, fitando apenas alguns pontos desse que nos ofereceimenso e animado panorama? Sim: o belo fenomenal se mostra com a maior pompa neste solo afortunado; e não poucos artistas brasileiros e estrangeiros beberam nele a inspiração mais pura, a inspiração criadora de obras excelentes, revestidas de vivas cores, de danosas formas, idealizadas nas harmonias da arte musical e poética.

A interferência do clima na mentalidade e comportamento dos indivíduos constituía uma tese popularizada por M adame de Staël, graças à qual separara as literaturas do Norte e as do Sul ${ }^{29}$. O conceito da cor local responsabilizava-se pela passagem dessa propriedade da natureza para a poesia, capaz de traduzir as emanações do espaço para o texto literário. Como cada cenário apresentava particularidades irrepetíveis, a literatura englobava essas singularidades e expunha seu caráter nacional. O Brasil, desde os primeiros anos da colonização descrito e entendido a partir do prisma das qualidades que a natureza, rica e exuberante, apresentava, só poderia gerar uma singular arte literária, independentemente da língua importada da E uropa, em particular do nem sempre na época benquisto Portugal.

O desenvolvimento do raciocínio de Santiago Nunes Ribeiro não deixa dúvida, reconhecendo a existência de um caráter nacional que, alojado na literatura, faculta considerá-la nativa. Um silogismo acompanha a exposição dessa idéia:

Agora perguntaremos se um país, cuja posição geográfica e constituição geognóstica, cujas instituições, costumes e hábitos tanto diferem da sua metrópole de outrora, não deve ter sua índole especial, seu modo próprio de sentir e conceber, dimanante destas diversas causas, modificadas umas pelas outras; se, numa palavra, não deve ter caráter nacional. Sim, nos dirá todo aquele que estiver desprevenido. A literatura é a expressão da índole, do caráter, da inteligência social de um povo ou de uma época. A poesia é a mais subida forma de literatura: ela procura compreender e exprimir por meio da linguagem o que há de mais belo, puro e santo na vida exterior do século, ou na vida misteriosa da intima consciência: as outras artes são formas secundarias desta.

Ora, se os brasileiros têm seu caráter nacional, também devem possuir uma literatura pátria.

Garantido o fato de que "a literatura brasileira tem seus predicamentos peculiares, e que se distingue da portuguesa por alguns traços característicos", o que sinaliza sua posição perante a produção contemporânea, Santiago N unes Ri-

29 Cf. STAËL, M me. de. Dela Littérature. Paris: Flammarion, 1991. E Del'Allemagne. Paris: G arnier-F lammarion, 1968. 2v. 
beiro vai atrás de sua história, visando então assegurar-Ihe não qualquer passado, e sim um em que as marcas de nacionalidade e peculiaridade estejam presentes. Para isso, ele precisa contradizer prestigiados antecessores como Ferdinand Denis, Almeida G arrett e J oaquim Norberto, advogando que:

Nós queremos provar que a acusação de imitadora, de estrangeira, de cópia de um tipo estranho, feita à poesia brasílica, é mal fundada, injusta e até pouco generosa. E m seguida tentaremos fazer o paralelo dos poetas brasileiros e portugueses, e terminaremos com algumas observações sobre a fixação das épocas da história literária do B rasil.

Seus pressupostos procedem, também dessa vez, da sociologia da literatura, cujos parâmetros permitem-Ihe mostrar-se sensível às características de época que toda produção artística apresenta. Assim, pode discordar da avaliação da obra de Tomás Antônio G onzaga, procedida por Garrett:

Este último deplora que os poetas brasileiros não empregassem a cor local para dar vivacidade aos seus painéis. Em Gonzaga especialmente nota esta falta de nacionalidade e acrescenta que, em vez de metamorfosear a sua Marília numa pastora, deveria fazê-la descansar à sombra das palmeiras, e orná-la com grinaldas de roxos martírios, ou com as cândidas flores dos bagos do lustroso cafezei ro. O poeta fez coisa melhor: deu a essas liras consagradas ao seu ídolo o abandono, o mimo, a graça indefinível da paixão satisfeita e venturosa. M ais adiante mostraremos que a disposição dos espíritos não permitia que a natureza fosse encarada sob o aspecto que hoje nos agrada tanto, e que não é lícito exigir de um século aquilo que ele não pode dar.

O mesmo argumento faculta-lhe contestar $\mathrm{G}$ onçalves de $\mathrm{M}$ agalhães, que exige da poesia uma atitude impraticável à época em que foi produzida:

A poesia brasileira da época anterior à independência foi o que devia ser. Porventura poderia ela ser a expressão das idéias e sentimentos de outros tempos? Se ela falasse a linguagem do sentimentalismo e do lirismo da Alemanha, ou a do descritivismo da escola do lago, poderia ser compreendida? Mas que dizemos? Quem Ihe houvera ensinado essa linguagem? Ninguém pode sentir inspirações completamente estranhas ao seu tempo.

Ao contrário de seus interlocutores, como Garrett e Magalhães, que, como chefes de escola, condenavam os poetas por não terem introduzido em suas obras padrões que somente eles próprios iriam adotar e a seguir impor às letras de seu 
tempo, Nunes R ibeiro compreende que cada autor acompanha os valores vigentes à época, não cabendo a ele antecipar programas estéticos que, séculos ou décadas depois, serão considerados prioritários. Assim, escreve, a propósito de Cláudio M anuel da Costa, que, se ele "não poetava na linguagem que hoje está na moda, ao menos fazia belos versos", valendo-se do soneto "Leia a posteridade..." para ilustrar a idéia. Capaz de perceber as diferenças de cânones, logo, as transformações provocadas não apenas pelo clima, mas também pelo tempo, Santiago ataca aqueles que exigem para todas as faixas cronológicas a concretização dos valores do presente, usando como exemplo os ícones típicos do Romantismo brasileiro, que contrapõe às imagens empregadas pelo árcade mineiro no poema mencionado:

Digam-nos agora se de um poeta que deplora a falta dos primores de outro clima se devia esperar a descrição de objetos que ele reputa prosaicos e contrários à inspiração. Que lhe importam as palmeiras a ele que não vê o álamo copado nem as venturosas praias de Arcádia? Não podia pois este poeta pintar o que para ele não era poético.

Sua conclusão é definitiva: “a poesia do B rasil é filha da inspiração americana". Para justificar a afirmação, amplia a base de apoio: não apenas o clima, mas também o solo levou os escritores a criar uma arte própria, diversa da européia, ainda quando eles, como quiseram, cada um a seu modo, Garrett e Magalhães, tiverem passado pelo filtro da educação recebida no Velho Continente:

O gênio dos brasileiros pertence ao clima, ao solo, ao Brasil finalmente. Assim em vez de considerar a poesia do Brasil como uma bela estrangeira, uma virgem da terra helênica, transportada às regiões do novo mundo, nós diremos que ela é a filha das florestas, educada na velha E uropa, onde a sua inspiração nativa se desenvolveu com o estudo e a contemplação de ciência e natureza estranha.

Ao designá-la "filha das florestas", Nunes Ribeiro contesta o líder do R omantismo carioca, que a acusara de ser não uma "indígena civilizada", e sim "uma grega vestida à francesa, e à portuguesa". R econhece que ela "se apraz ainda com as reminiscências da pátria", como queria Magalhães, mas as razões diferem:

Ora, se ela se lembrou tanto do Brasil é por que o tinha por sua pátria e assim experimentava o sentimento da sua nacionalidade. Sem dúvida algumas vezes esta saudade só se revelou em duas palavras, ou num ai sentido: mas cumpre atender ao estado em que o espírito do brasileiro está na Europa. Oprimido pelas sensações, tentado a ver tudo quanto a arte fez de grande, e engrandecendo mais as coisas pelo seu gênio entusiasta, nem sempre tinha ocasião de recolher-se e 
meditar. Sua imaginação brilhante como o céu dos trópicos, apaixonada pelo novo e maravilhoso, dilatava a esfera da ciência e da arte.

E is por que é possível escrever uma história para a literatura brasileira, pois esta dispõe de um passado em que a "nacionalidade" ou o "nacional" já se apresentavam, variando conforme o gênero em que os autores se expressavam. Com essa certeza na cabeça, Santiago propõe a divisão da poesia nacional em "três períodos": visando distinguir as épocas artísticas, prefere, ao critério cronológico adotado por Ferdinand Denis, Almeida G arrett e J oaquim Norberto, uma repartição de ordem temática e estética, originarias das características dos autores.

O ensaio de Santiago Nunes Ribeiro deve ter provocado repercussões, porque, no número subseqüente da Minerva Brasiliense, o autor responde aos que rejeitaram suas proposições. No terceiro volume da revista, o Cônego J anuário da Cunha B arbosa reproduz "extrato do discurso de M. Mennechet, lido no congresso histórico reunido em Paris neste ano de 1843 sobre a nacionalidade da literatura", contribuindo para o esclarecimento de uma questão "suscitada pela Minerva e de que muitos literatos se ocupam, sem contudo assentarem as verdadeiras bases em uma satisfatória definição".

Talvez o tema carecesse de solução por faltarem testemunhos artísticos para a desejada autêntica literatura nacional, problema provavelmente solucionado com a publicação, em 1847,dos Primeiros Cantos, de Gonçalves Dias, autor que, atuando, junto com Araújo Porto Alegre e J oaquim Manuel de Macedo, na Guanabara, sucessora, em certo sentido, da Minerva B rasiliense, integrou-se aos debates que envolviam os intelectuais brasileiros residentes no Rio de J aneiro.

O reconhecimento de que Gonçalves Dias alcançou concretizar o anelo dos historiadores e críticos românticos, por extensão, da sociedade brasileira ou, ao menos, da elite dirigente que almejava conferir ao país um sentimento de unidade sintetizado na noção de nacionalidade, aparece no estudo que lhe dedicou M acedo Soares. Responsável, em 1859, por uma antologia de poemas contemporâneos, Harmonias Brasileiras, ele mostrou-se bastante atento à produção literária em circulação a seu tempo. E m 1860, escreveu um ensaio dedicado ao livro de poemas Flores Silvestres, escrito por B ittencourt Sampaio, participante da coletânea anterior. Ao abrir o estudo, toma de imediato posição relativamente à questão da nacionalidade da literatura, questionando parecer de J oaquim Norberto:

E u não sei, apesar da opinião respeitada do Dr. J . Norberto, como se pode separar a originalidade da nacionalidade: porquanto ser nacional, isto é, de seu século e país, equivale a ter feições próprias suas, um caráter distinto e peculiar, uma fisionomia original: e não é nacional a literatura que não distingue um povo na 
comunhão dos outros povos. Sem crenças, nem tradições, despida de cores locais, carecedora do cunho da imaginação popular, a poesia cosmopolita pertence a todos pro indiviso, entra no domínio das idéias gerais de que todos podemos apropriar-nos sem plagiato. ${ }^{30}$

M acedo Soares não distingue nacionalidade e originalidade, send o a primeira condição para a segunda, pois não oferece meios de ser copiada. A recorrência à cor local, no trecho claramente manifestada, assegura o caráter nativista do texto, bem como o protege contra cópias ou a dissolução num patrimônio cultural indiferenciado. No estudo sobre G onçalves Dias, volta a essa tópica, começando por historiá-la. R evisa, primeiramente, o assunto, concluind o que seu aparecimento se deu na década de 40, época em que os "os literatos debatiam a grande questão da nacionalidade, a fórmula poderosa e enérgica do novo espírito da sociedade", não encontrando, contudo, saída para as dificuldades enfrentadas:

estudavam os escritores e poetas dos séculos XVII e XVIII para confirmação de suas teses, e se não desanimavam, não era porque descobrissem tesouros encobertos nas obras do passado; pois era portuguesa demais a poesia colonial para satisfazer a solução do problema. ${ }^{31}$

A virada deveu-se ao aparecimento do livro de estréia de Gonçalves Dias, que provocou uma modificação no gosto, rejeitando os resíduos ainda existentes de Classicismo, e complementou a tarefa a que se dedicou Magalhães:

Os Primeiros Cantos vieram verificar a teoria, e mostraram que o Pindo não vale uma colina do Novo M undo, nem as ninfas do Mondego uma borboleta das nossas Campinas, nem A polo uma piaga, nem Hércules um guerreiro da tribo tupi. Realizaram uma tendência da literatura, um desejo intenso dos homens de arte, uma aspiração nacional. Foram o complemento da obra do Sr. Magalhães e uma necessidade da quadra. Festejada pelo povo e aceita pelos pensadores, a arte nova achouse entronizada quase sem o saber: não houve perseguidores nem mártires, não precisou ocultar-se nos hipogeus, nem vestir alva aos catecúmenos para a iniciação. Era, repito, uma necessidade do tempo. ${ }^{32}$

A conclusão de que Gonçalves Dias resolveu os dilemas até então experimentad os pela literatura e pela crítica brasileira expressa-se no parágrafo final do ensaio. Macedo Soares rejubila-se com o poeta que logrou liberar a poesia nacional, até então agrilhoada à tradição arcádica e, portanto, desnacionalizada:

30 SOARES, Antônio J oaquim de Macedo. F lores Silvestres. In: ed. cit. Originalmente publicado em: Revista Mensal do Ensaio Filosófico Paulistano, n. 5, agosto de 1860, p. 65-72.

$31 \quad$ Idem, p. 98.

$32 \quad$ Idem, p. 98. 
Ao Sr. Gonçalves Dias compete o primeiro lugar entre os primeiros poetas da geração nova; a ele a honra de ter trazido do seio das flores a planta da poesia nacional e completado a nossa emancipação do jugo da Arcádia; e ele a glória da era nova aberta aos destinos da arte brasileira. ${ }^{33}$

A crença de que a questão estava resolvida não tarda a se mostrar ilusória. J osé de Alencar, em "B ênção Paterna”, que introduz Sonhos D'Ouro, discute o tópico a propósito de sua própria obra. Dialogando com o texto de ficção que se segue ao prólogo crítico, A lencar tenta antecipar as restrições de que será objeto. P rimeiramente, supõe que o ataque provirá daqueles que o julgam comercial, mais preocupado com os ganhos financeiros que os estéticos; depois, conjetura que o defeito a ser atribuído ao romance decorrerá de estar ele "um tanto desbotado do matiz brasileiro, sem aquele picante sabor da terra"34. A razão para tal juízo é o fato de ser o B rasil acusado de não ter literatura própria, incriminação originária da ex-M etrópole, pois “lá uns gênios em Portugal, compadecendo-se de nossa penúria, tomaram a si decidir o pleito, e decretaram que não temos, nem podemos ter literatura brasileira". O curioso, para ele, é que "a grande inteligência de Alexandre Herculano nos profetizara uma nacionalidade original, transfusão de duas naturezas, a lusa e a americana, o sangue e a luz"; mesmo assim, afirma, "os ditadores não o consentem; que se há de fazer? R esignemo-nos".

A resignação veste a forma de uma ironia: "este grande império, a quem a Providência rasga infindos horizontes, é uma nação oca; não tem poesia nativa, nem perfume seu; há de contentar-se com a manjerona, apesar de ali estarem recendendo na balça a baunilha, o cacto e o sassafrás". Alencar não se diz ofendido e proclama humild ade e conformismo, resumidos no diminutivo "livrinho" com que trata seu romance, a quem se dirige no prefácio. O ficcionista sabe, contudo, que sua obra está empenhada na construção da sociedade nacional, cujo projeto de representação detalha no mesmo prólogo. Substitui-se o historiador da literatura, como fora Nunes Ribeiro, pelo narrador da história de um povo, que aparece de modo segmentado em diferentes novelas, desde as indianistas como I racema e O Guarani, até as que traduzem a vida fora dos centros urbanos, como O Tronco do I pê, ou a sociedade contemporânea, matéria de Diva, Lucíola e do livro que está sendo apresentado.

A consciência de que compete à literatura trabalhar para a constituição da nacionalidade aparece mais adiante, justificando a operosidade do romancista que assina a apresentação. A pelando aos críticos para que dispam os prejuízos perante

Idem, p. 116.

ALENCAR, J osé de. "B ênção Paterna". In: Sonhos D’Ouro. 4 ed. Rio de J aneiro: J osé Olympio, 1957. 
a literatura vigente, formula como entende "a missão dos poetas, escritores e artistas, nesse período especial e ambíguo da formação de uma nacionalidade":

São estes os operários incumbidos de polir o talhe e as feições da individualidade que se vai esboçando no viver do povo. Palavra que inventa a multidão, inovação que adota o uso, caprichos que surgem no espírito do idiota inspirado; contudo isto lança o poeta no seu cadinho, para escoimá-lo das fezes que porventura Ihe ficaram do chão onde esteve, e apurar o ouro fino.

Alencar atribui ao poeta papel de liderança, exercida a partir do trato com a linguagem. Tal como Almeida G arrett e Gonçalves de Magalhães, compreende a criação literária desde o lugar onde trabalha, maximizando sua função, como que a justificar-se, mas ao mesmo tempo precavendo-se da crítica desfavorável. Seu entendimento do nacional passa pela representação, executando o projeto que estava na cabeça de muitos; mesmo assim, não se considera satisfeito, e lamenta os preconceitos de que se acreditava objeto. Cinqüenta anos depois da formulação das primeiras exigências de exercício da nacionalidade na literatura, as promissórias continuavam a ser cobradas.

No ano seguinte, contudo, Machado de Assis manifestava seu descontentamento diante dessa idéia.

O desagravo aparece no ensaio "Notícia da Atual Literatura Brasileira", originalmente publicado em New World, revista dirigida por Sousândrade. O texto retoma, em boa parte, concepções previamente expostas em “O Passado, o Presente e o Futuro da Literatura", que Machado de Assis, em 1858, então com dezenove anos, colocara em A Marmota, periódico patrocinado por Paula B rito. Nesse trabalho da juventude, Machado principia pelo exame do teor geral da poesia e da cultura em seu tempo para, a seguir, analisar a produção contemporânea, dividindo-a conforme o gênero literário a que se integra, procedimento repetido no estudo posterior. Mas há algumas diferenças dignas de nota: o jovem $\mathrm{Ma}$ chado inicia o ensaio, endossando a perspectiva então dominante da historiografia da literatura, condenando os escritores do século XVIII por terem-se deixado dominar pela estética européia, a que imitavam:

A poesia de então tinha um caráter essencialmente europeu. Gonzaga, um dos mais líricos poetas de língua portuguesa, pintava cenas da Arcádia, na frase de Garrett, em vez de dar uma cor local às suas liras, em vez de dar-Ihes um cunho puramente nacional. Aqui uma grande perda: a literatura escravizava-se em vez de criar um estilo seu, de modo a poder mais tarde influir no equilíbrio literário da América. ${ }^{35}$ 
O futuro novelista apossa-se do jargão em voga; calcado no parecer de Almeida G arrett, a quem sempre admirou, exigia de $G$ onzaga que suas liras contivessem "cor local", lamentando a ausência de "cunho puramente nacional". A conclusão para tão sinistra situação abre o parágrafo seguinte: "Todos os mais eram assim: as aberrações eram raras", e ficam por conta de B asílio da G ama principalmente, cujo Uraguai é considerado "valiosa exceção". Machado explica por quê: "Sem trilhar a senda seguida pelos outros, G ama escreveu um poema, se não puramente nacional, ao menos nada europeu". A explicação, por sua vez, trai a contradição: o Uraguai ainda não era puramente naci onal, embora Almeida G arrett, guia intelectual de Machado de Assis nessa matéria, tenha considerado o poema de B asílio "verdadeiramente nacional", e sua poesia, "legítima americana". A diferença conceitual esclarece-se logo a seguir:

Não era nacional, porque era indígena, e a poesia indígena, bárbara, a poesia do boré e do tupã, não é a poesia nacional. O que temos nós com essa raça, com esses primitivos habitadores do país, se os seus costumes não são a face característica da nossa sociedade?

A tomada de posição parece politicamente incorreta, mas responde a questões em pauta, nesse final dos anos 50: o Indianismo, na poesia, estava consolidado enquanto manifestação mais adequada da poesia nacional, graças ao trabalho dos dois G onçalves, que andavam a braços com a criação de uma epopéia, seja, de Magalhães, A Confederação dos Tamoios, de 1855, rejeitada bravamente por J osé de Alencar, seja, de Dias, Os Ti mbi ras, poema que permaneceu inacabado embora parcialmente publicado por aquela época. Alencar, da sua parte, já fizera sucesso com O Guarani , e M achado corajosamente acusa não haver nenhuma relação "com essa raça", não podendo ela dar vazão à poesia nacional.

Em 1858, Machado esclarece, talvez para si mesmo, que poesia nacional e Indianismo não andam juntos, nem são sinônimos; mas, ainda dependente do juízo de Garrett, cobra de Gonzaga, que, ao contrário de Basílio, não elaborou "poesia indígena", a ausência da cor local em suas liras. O autor parece ainda indeciso perante assuntos que o atormentaram na juventude e continuavam vigorando na crítica sua contemporânea, haja visto o prefácio de J osé de Alencar aos Sonhos D'Ouro.

Talvez sejam os parágrafos iniciais de “Notícia da Atual Literatura Brasileira" os mais célebres. Pode-se cogitar que eles traduzem o diálogo de Machado de

35 ASSIS, Machado de. "O Passado, o Presente e o Futuro da Literatura". In: Obra Completa. Rio de J aneiro: Aguilar, 1958. 3v. 
Assis, em parte consigo mesmo, ao menos com o M achado que ele tinha sido quinze anos antes, em parte com os intelectuais a que tinha lido ou conhecido. E is por que abre o texto com o notório período, freqüentemente repetido: “Quem examina a atual literatura brasileira reconhece-Ihe logo, como primeiro traço, certo instinto de nacionalidade" ${ }^{36}$, notoriedade que transformou a expressão que encerra a frase em título do ensaio. "Instinto de nacionalidade" corresponde, porém, a uma torção conceitual; falava-se até então de "caráter nacional”, "índole nacional" ou "espírito nacional", não de instinto, substantivo que materializa um sentido, ao substituir vocábulos que tendiam ao incorpóreo.

Logo a seguir, o romancista esclarece o que entende por esse conceito, retomando, na explicação, o jargão da estética romântica que acompanhou de perto: "P oesia, romance, todas as formas literárias do pensamento buscam vestir-se com as cores do país". Mais adiante, ele sinaliza as vantagens de tal procedimento: "I nterrogando a vida brasileira e a natureza americana, prosadores e poetas acharão ali farto manancial de inspiração e irão dando fisionomia própria ao pensamento nacional." 37

Também na crítica Machado verifica que essa atitude é adotada: "sente-se aquele instinto até nas manifestações da opinião", que, no entanto, considera "mal formada ainda", ao agir como age: "Há nela um instinto que leva a aplaudir principalmente as obras que trazem os toques nacionais." ${ }^{38}$

É nesse ponto que a carapuça parece caber no próprio crítico, pois as frases seguintes aplicam-se a ninguém menos que ao autor, lembrando o estudo publicado quinze anos antes:

\begin{abstract}
A juventude literária, sobretudo, faz deste ponto uma questão de legítimo amorpróprio. Nem toda ela terá meditado os poemas de Uruguai [sic] e Caramuru com aquela atenção que tais obras estão pedindo; mas os nomes de Basílio da Gama e Durão são citados e amados, como precursores da poesia brasileira. ${ }^{39}$
\end{abstract}

Quando chega a vez de Gonzaga, Machado maduro parece puxar as orelhas do jovem de antanho, que condenara o poeta por não saber "desligar-se das faixas da Arcádia nem dos preceitos do tempo. Admira-se-lhes o talento, mas não se Ihes perdoa o cajado e a pastora, e nisto há mais acerto que erro."40

\footnotetext{
36 ASSIS, M achado de. "Literatura B rasileira - Instinto de Nacionalidade". In: Crítica Literária. São Paulo: M érito, 1959. p. 129. 
Também M achado parece desmentir-se quando examina a poesia indianista, exemplar, segundo ele, do instinto que verifica existir na literatura e na crítica. Tornando a reconhecer que "a civilização brasileira não está ligada ao elemento indiano, nem dele recebeu influxo nenhum"( o que matiza a afirmação intempestiva do estudo anterior), aceita que a vida indígena possa aparecer nos versos dos líricos, pois "tudo é matéria de poesia, uma vez que traga as condições do belo ou os elementos de que ele se compõe." 41 A conclusão é definitiva, resolvendo os dilemas do escritor: "Erro seria constituí-lo um exclusivo patrimônio da literatura brasileira; erro igual fora certamente a sua absoluta exclusão." 42

Traçando o percurso da literatura brasileira até seu tempo, Machado está marcando o caminho com as ped rinhas do erro; três vezes ele a usa, para sinalizar o que não se deve pensar, procurando fugir dos extremos, de que uma vez esteve perto. A quarta anotação que reprime o erro é a mais conhecida de todas:

Devo acrescentar que neste ponto manifesta-se às vezes uma opinião, que tenho por errônea: é a que só reconhece espírito nacional nas obras que tratam de assunto local, doutrina que, a ser exata, limitaria muito os cabedais de nossa literatura.43

R ejeitando a relação de causa e conseqüência entre "espírito nacional" e "assunto local", Machado emite seu principal juízo crítico:

O que se deve exigir do escritor antes de tudo, é certo sentimento íntimo, que o torne homem do seu tempo e do seu país, ainda quando trate de assuntos remotos no tempo e no espaço. ${ }^{44}$

Machado deixa claro o metro que emprega para avaliar a literatura, medida que, segundo ele, fortaleceria a crítica e, por extensão, a literatura, beneficiária de um julgamento criterioso segundo normas estéticas, e não programáticas, quando da valoração das obras:

A falta de uma crítica assim é um dos maiores males de que padece a nossa literatura; é mister que a análise corrija ou anime a invenção, que os pontos de doutrina e de história se investiguem, que as belezas se estudem, que os senões se apontem, que o gosto se apure e eduque, para que a literatura saia mais forte e viçosa, e se desenvolva e caminhe aos altos destinos que a esperam. ${ }^{45}$

\footnotetext{
$41 \quad$ Idem, p. 132.

42 Idem, ibidem.

43 Idem, p. 134.

$44 \quad$ Idem, p. 135.

$45 \quad$ Idem, p. 136.
} 
A exigência revela, de um lado, o crédito que o autor confere ao analista, expresso, aliás, antes em “O I deal do Crítico", de 1865; de outro, aponta para uma falta, a de uma historiografia confiável da literatura. Desde a primeira década da independência, a história da literatura vinha se empenhando em estabelecer esses padrões, assimilando valores da poética romântica européia e tentando atrair autores do presente e do passado para as hostes consideradas representativas da nacionalidade. A denúncia de Machado de Assis, que o inclui de certo modo, enquanto devoto por um tempo do instinto que agora renega, sinaliza o fracasso do projeto romântico de historiografia da literatura.

Por outro lado, pode-se pensar que, de certa maneira, o escritor está marcando o final de um percurso: o seu, pessoal, porque o crítico começa a ceder lugar ao ficcionista, responsável por uma obra que ignora o denunciado "instinto de nacionalidade"; e o da historiografia e crítica romântica brasileira que, doravante, adota o cientificismo propugnado pelo Positivismo, sublinhando de modo crescente a importância da formação racial. Sílvio Romero é o porta-voz da nova tendência, conforme a qual o elemento português se amalgama ao negro, construindo o protótipo brasileiro, configurado no mestiço.

Abre-se outro horizonte de leitura do passado e do presente, fenômeno flagrado, sob diferentes perspectivas, por Machado de Assis e Sílvio R omero, traduzindo-o cada um à sua moda, o primeiro no romance e o segundo, na história da literatura e na crítica literária, e ocupando as últimas décadas do século XIX.

\section{Crítica Científica e História da Literatura}

A Sílvio R omero (1851-1914) atribui-se a primogenitura da história da literatura brasileira: desde o título, o livro contendo essa matéria, de 1888, propõe-se a narrar, dos inícios à atualidade do autor, a trajetória da produção literária do país. J osé Veríssimo (1857-1916) desembarca no R io de J aneiro poucos anos depois, colaborando na imprensa carioca a partir de 1891; sua História da literatura brasileira apareceu em 1916, ano de sua morte. Os dois intelectuais atuaram em períodos próximos, mas 25 anos separam suas obras mais importantes, balizando fase significativa, contudo nem sempre suficientemente conhecida, da vida literária nacional.

As circunstâncias que os avizinham parecem fortuitas: nascidos longe do $\mathrm{R}$ io de $\mathrm{J}$ aneiro, migraram adultos para a Corte, onde desenvolveram atividades similares; redigiram uma história da literatura brasileira; faleceram em torno a 1915. A discórdia mostra-se mais notável, pois disputaram pontos de vista opostos e inconciliáveis, a ponto de R omero publicar em 1910 Zeverí ssi mações ineptas da crítica, agredindo o oponente. Por sua vez, a época em que atuaram, limitada pelas datas de suas respectivas Histórias, de 1888 a 1916, é das mais férteis, contu- 
do, paradoxalmente menosprezada: "sorriso da sociedade"46 para Lúcia MiguelPereira, para Alceu A moroso Lima e A Ifredo Bosi, Pré-M odernismo, rótulo inadequado que aglomera fatores diversos e até incompatíveis. Uma reflexão sobre as obras de Romero e Veríssimo talvez ajude a entender a razão do desprestígio da época de que participaram.

Primeiro historiador da literatura brasileira a se conferir esta designação, Sílvio Romero trilhou a picada aberta pelos citados românticos, Gonçalves de Magalhães, Pereira da Silva, J oaquim Norberto e Varnhagen, que pesquisaram dados fundamentais, necessários à sistematização do passado, não apenas ordenando elementos conhecidos, mas criando fatos, ao descobrir autores, obras, inéditos. Sem esse trabalho preparatório, cujo valor, mas sem entusiasmo, R omero reconhece, o esforço historiográfico não poderia se concretizar. Contudo, o que ele pretende é, a partir do material coletado, verificar seu sentido e testar a evolução, desde princípios teóricos fundados na ciência de seu tempo.

A preocupação de Romero com a história da literatura brasileira já se manifesta em A literatura brasi leira ea crítica moderna, de 1880, em que "formula sistematicamente a sua teoria crítica" ${ }^{47}$, calcada em Taine, de quem recebe as noções de raça, meio e momento. Na Introdução à história da literatura brasileira, de 1881, desenvolve os princípios deterministas, ao propor que o elemento racial predomina na formação da cultura brasileira, destacando-se o processo de mestiçagem.

Ao enfatizar a raça como fator de formação, R omero está observando os elementos postos em relevo pela metodologia de Taine. Mas só de modo parcial, porque tem em mente as distintas etnias que participaram da constituição da nacionalidade, o negro, o índio e o branco, enquanto que o francês lida apenas com a arte européia, diferenciada conforme os povos, que considera raças. Além disso, Taine, provavelmente nas pegadas de Staël, salienta a atuação do meio, fator que sobrepõe aos demais. Romero não aceitava a idéia, trabalhada pelos românticos, para quem a literatura brasileira se distinguia, porque poetas e intelectuais não tinham resistido à ação da natureza pujante da A mérica. E m lugar do meio, propõe raça enquanto fator decisivo, o que é metodológica e ideologicamente inovador, e salienta a contribuição do negro, posicionando-se na contramão do até aí hegemônico "partido indianista", modo como designa os seguidores da vertente romântica. Ao enfatizar a miscigenação, aborda "a história nacional sob a perspectiva da luta e da fusão de raças."48

46 MIGUEL-PEREIRA, Lúcia. Prosa de ficção - de 1870 a 1920. 3 ed. B rasília: Instituto Nacional do Livro/R io de J aneiro: J osé Olympio, 1973.

47 CANDIDO, Antonio. Sílvio Romero. Teoria, crítica e história literária. Seleção e Apres.:Antonio Candido. Rio de J aneiro: Livros Técnicos e Científicos/ São Paulo: Edusp, 1978. p. XV.

48 VENTURA, Roberto. Estilo tropical. História cultural e polêmicas literárias no Brasil. São Paulo: Companhia das Letras, 1991. p. 90. 
O lançamento da História da L iteratura B rasileira ocorre em 1888 e completase em 1902, essa sendo a edição de referência da obra, embora, atualmente, circule em cinco volumes, graças ao trabalho de compilação executado por Nelson R omero, que incorporou ao texto original materiais de natureza e épocas diversas ${ }^{49}$. 0 prólogo da primeira edição não deixa de fazer alusões ao momento em que o livro é publicado, após a conquista da liberdade pelos negros, mas antes da implantação da República, movimento que conta com a solidariedade do autor. Datando-o ostensivamente de 18 a 19 de maio de 1888, declara sua opção política: partidário da "emancipação autonômica e popular", diz-se "sectário da república uni tária, livre, autônoma, compatível com a boa e vasta descentralização administrativa e econômica e compatível também com a unidade política, espiritual e étnica do país"50. A produção da História da literatura brasileira integra-se a esses princípios, por não dissociar o exercício da política e o da crítica literária: “Inspirei-me sempre no ideal de um B rasil autônomo, independente na política e mais ainda na literatura. Desse pensamento inicial decorreram todas as minhas investidas no domínio das letras"51.

Tal afirmação exemplifica a coerência com que Sílvio R omero exerce sua atividade de crítico literário, historiador da literatura e homem de partido. Contaminando a história da literatura de ideário político, torna-a efetivamente polêmica, objetivo que buscou e atingiu: as interpretações nem sempre são aceitáveis, a escolha de certos autores revela gosto duvidoso, as recusas parecem movidas pela afronta. Tudo isso, contudo, resulta das finalidades que o levaram à produção da obra, escrita sob o clima de paixão declarado no prólogo, que contamina os diferentes capítulos, e destinada a fazer com que os intelectuais brasileiros refletissem sobre o passado e o presente da literatura e da cultura nacional.

O Livro I, sobre os "Fatores da Literatura Brasileira", dedica-se a questões teóricas e metodológicas, expondo a tese fundamental que norteia sua interpretação da vida nacional - a mestiçagem: “Todo brasileiro é um mestiço, quando

Na terceira edição do v. 1, Nelson R omero acrescenta: “N ovas contribuições para o estudo do folclore brasileiro", em três partes; “o B rasil social e os elementos que o plasmaram”, “Conclusões gerais”, retiradas do Compêndio de literatura brasileira (segunda edição, de 1909) e contendo “I. O meio; II. A raça; III. Influxo estrangeiro; IV. Sentido teórico da literatura brasileira; V. Fases evolutivas da literatura brasileira"; "Da crítica e sua exata definição". N elson R omero introduz no v. II: "Terceira época ou período de transformação romântica - teatro e romance", contendo estudo sobre “Martins Pena”, “Macedo", "Alencar, Agrário, Manuel de Almeida, Pinheiro Guimarães, F ranklin Távora, Taunay”, "M achado de Assis"; "Diversas manifestações na prosa - história", contendo estudo sobre M artius e "historiadores"; “Diversas manifestações na prosa - publicistas e oradores", “R etrospecto literário", contendo "R etrospecto literário", de 1888, e “Confronto em retrospecto", de 1904; “R eações anti-românticas na poesia - evolução do lirismo", “Artigos esparsos" sobre J oão R ibeiro, Lopes Trovão, T ito Lívio de Castro, J osé do Patrocínio, B arão do R io B ranco, J oaquim Nabuco, Farias Brito, Nestor Vitor e Euclides da Cunha; “Quadro sintético da evolução dos gêneros na literatura brasileira", incorporando o livro com este nome, de 1909. 
não no sangue, nas idéias" 52 ; o mestiço consiste "genuína formação histórica brasileira"53, "produto fisiológico, étnico e histórico do B rasil; é a forma nova de nossa diferenciação nacional"54 . A mestiçagem constitui o fator de diferenciação preferido por Romero, escolha que contradiz a tradição de eleger a natureza enquanto expressão da especificidade brasileira. Contudo, R omero não deixa de emitir conceitos racistas, porque considera a fusão racial modo de aviltamento, superável com a vitória, pela via da seleção natural, do povo mais forte, o branco, de extração européia.

A originalidade do fator adotado por Sílvio R omero não exclui a incorporação dos preconceitos étnicos enunciados no final do século XIX; mas ele não contrariava contemporâneos como Euclides da Cunha, que entendeu o massacre de Canudos como a vitória da civilização branca e eu ropéia sobre a barbárie sertaneja, constituída de indivíduos inferiores graças aos intercursos entre diferentes grupos biológicos, afetando a formação genética da população. De todo modo, R omero introduz dados novos, como o fator racial e o mestiço, na interpretação da vida nacional; os estudiosos da cultura brasileira demoraram a absorvê-lo, tendo de aguardar a explosão modernista, para admitir a mestiçagem e a confluência dos povos.

M uniciado pela sociologia positivista, R omero inclui no Livro I capítulo relativo às relações econômicas, em que analisa as instituições políticas e sociais da colônia e do I mpério. Para ele, "o estado de riqueza ou pauperismo de um povo influi diretamente na formação de sua literatura" ${ }^{55}$, este sendo o caso do Brasil, cuja economia se caracteriza pela dominação estrangeira e o coronelismo. E is por que os movimentos literários durante quatrocentos anos de história reduzem-se à escola baiana do século XVII, liderada por G regório de M atos, à escola mineira do século XVIII, dominada por G onzaga e Durão, à fluminense da primeira metade do século XIX, em que se destacaram Gonçalves de Magalhães e Gonçalves Dias; "e finalmente sobre todos estes movimentos isolados de uma ou outra província, o grande abalo naci onal, [...] torrente ainda mal definida, hasteando todas as bandeiras, mas tendo um só alvo: - a mutação social"56

O retrato da atualidade é melancólico, dada a "completa indiferenca pelo que é produto intelectual brasileiro" 57 , de que conclui: "A grande pobreza das classes populares, a falta de instrução e todos os abusos de uma organização civil e social defeituosa, devem ser contados entre os empecilhos ao desenvolvimento de

\footnotetext{
Idem, p. 4.

Idem, p. 54

Idem, p. 75

Idem, p. 94

Idem, p. 12

Idem, p. 97
} 
nossa literatura"58. Mas a palavra de ordem não é menos enérgica: considerando que "todo escritor nacional na hora presente está carregado do imperioso dever de dizer toda a verdade a nosso povo, ainda que pelo rigor tenha de desagradar geralmente" 59 , propõe: “Tomemos todos os encargos que os séculos nos legaram e aparelhemo-nos para solvê-los"60.

Na seqüência, examina as quatro épocas das Letras brasileiras: a) formação ( 1500 e 1750); b) desenvolvimento autônomo (1750 e 1830); c) transformação romântica ( 1830 e 1870); d) reação crítica (depois de 1870). Na edição de 1888, R omero trata dos dois primeiros períodos; o Romantismo será matéria de análise na edição de 1902; o último período, de "reação crítica", do qual ele mesmo faria parte, não chegou a ser escrito. A partir dos anos 90, Sílvio R omero dedicou-se à política, afastando-se do estudo sistemático da história literária. Seu trabalho subseqüente aparece em Evolução da literatura brasi lei ra e Evolução do lirismo brasileiro (1905); Compêndio de literatura brasi lei ra (1906), com J oão Ribeiro; Quadro sintético da evolução dos gêneros na li teratura brasileira (1909) , obras que não fogem ao panorama desenhado pela História da literatura brasileira, mas de destino escolar e caráter menos controverso. O Sílvio R omero por excelência, veemente polemista, está no livro de 1902, cuja metodologia, apoiada na sociologia, ainda vigora nos estudos literários brasileiros, depuradas dos componentes racistas e disfóricos.

Tal como Sílvio, J osé Veríssimo escreveu a História da literatura brasi lei ra após ter militado na crítica literária e no ensino. No Rio de J aneiro, para onde emigrou nos primeiros anos da R epública, trabalhou sobretudo em jornais, tendo dirigido também a Revista Brasileira, periódico de orientação cultural publicado de 1895 a 1899. O livro, cujo aparecimento público deu-se após sua morte, em 1916, corresponde ao coroamento de uma carreira, precedido pelos seis volumes dos Estudos de literatura brasilei ra, lançados entre 1901 e 1907. Assim, enquanto que a História da literatura brasileira de R omero vem na esteira de suas preocupações teóricas e metodológicas, a de J osé Veríssimo resulta de seu percurso na qualidade de crítico literário, a que se dedicou em tempo integral. O livro constitui o ponto de chegada de um trajeto que, iniciado pela verificação e análise de livros contemporâneos, conduziu o autor ao conhecimento das origens e trajetória, que, numa perspectiva evolutiva, acabam por desaguar com coerência no presente de onde partiu, sendo igualmente o momento de representação mais completa do conjunto.

\footnotetext{
Idem, p. 98.

Idem, p. 99.

Idem, p. 100.
} 
A "Introdução", datada de 4 de dezembro de 1912, de um lado, ilustra a noção de que a História da literatura brasil ei ra corresponde ao remate do itinerário do crítico, complementando-o; de outro, expõe as principais concepções do autor sobre a literatura nacional, sua rota histórica e a situação contemporânea. O cupa, nesse sentido, o mesmo papel do prólogo elaborado por Romero: é o lugar onde Veríssimo esclarece as teses que fundamentam a escrita do livro. A primeira posiciona-se quanto à questão da emancipação: afirmando que a literatura "que se escreve no Brasil" é “já a expressão de um pensamento e sentimento que se não confundem mais com o português"61 , elimina de imediato o tema da dependência, matéria que atormentara os românticos, empenhados em garantir a autonomia da poesia nacional em relação à matriz lusitana.

A convicção relativa à auto-suficiência da literatura brasileira determina a periodologia: Veríssimo reconhece tão-somente dois períodos, o colonial e o nacional, equivalente às divisões "na nossa história como povo"62. Recusa a hipótese de subdividir a época colonial, pois a produção elaborada nesse tempo é “inteira e estritamente conjunta à portuguesa"63, perspectiva que também o situa na contramão do Romantismo, quando os historiadores esforçavam-se por encontrar manifestações de nativismo, improvável devido ao estatuto político e cultural da região, mas possível em decorrência dos influxos da natureza. E le é radical no que concerne a esse tópico, julgando "desarrazoado" o fato, forçado, de "enxergar mostras de sentimento literário autonômico"64 nas expressões literária dos sécuIos XVII eXVIII. O período nacional, por seu turno, nasce com a separação política de Portugal e abre com o romantismo, cuja permanência estende-se até 1870; o esgotamento da poética romântica leva-o a discutir as tendências contemporâneas, detendo-se em particular no cientificismo, que não conta com sua admiração. E mbora parta de pressupostos radicalmente distintos, ele, tanto quanto R omero, desencanta-se com o que então presencia na arte e cultura brasileiras.

A terceira tese esposada pelo historiador da literatura resume-se a uma frase: “literatura é arte literária”65. O conceito, próximo do esteticismo formulado desde o século XVIII e que, no século XX, garantiu à literatura o desenho de um campo teórico específico, contradizia algumas práticas vigentes à época de Veríssimo: a dos românticos, que colecionavam todos os possíveis fatos literários do passado, para encorpar a tradição artística do país; e a de R omero, para quem a literatura

\footnotetext{
61 VERISSIM O, J osé. História da literatura brasileira. DeBento Teixeira (1601) a Machado de Assis (1908). 4 ed. B rasília: Ed. da Universidade de Brasília, 1963. p. 3.

Idem, p. 6 .

Idem, p. 6.

Idem, ibidem.

Idem, p. 12.
} 
servia de instrumento para se pensar a cultura, verificar rumos e avaliar tendências. Veríssimo opera com o corte e a censura, isolando a literatura, porque, de um lado, considera-a suficientemente independente para não ser atrelada à portuguesa, de outro, porque a julga apta a sustentar-se sem os suportes que a amarram aos estudos sociais.

O tripé escolhido - a autonomia da literatura brasileira após a independência política, a divisão histórica entre literatura colonial e nacional, o conceito de literatura enquanto arte literária - determina o percurso histórico, inaugurado por B ento Teixeira, a que se seguem manifestações isoladas e, de certo modo, descontínuas, representadas por individualidades como Gregório de Matos ou grupos pequenos, como a plêiade mineira. Veríssimo está mais interessado na literatura nacional, que mapeia com cuidado, embora privilegie os grupos que atuaram no Rio de J aneiro. R aramente se afasta do ponto de vista da Capital Federal, a antiga Corte que centralizava a vida cultural brasileira e que ele acaba por referendar. Talvez porque as expressões regionais não tivessem qualquer repercussão no coração do país, Veríssimo mostrando-se coerente com o princípio recepcional explicitado na "I ntrodução": "uma literatura [...] só existe pelas obras que vivem, pelo livro lido, de valor efetivo e permanente e não momentâneo e contingente"66; talvez porque estivesse mais interessado em alcançar logo o ápice, o capítulo dedicado a Machado de Assis, que abre de modo apoteótico: “chegamos agora ao escritor que é a mais alta expressão do nosso gênio literário, a mais eminente figura da nossa literatura, J oaquim Maria Machado de Assis"67

O final da História coincide com a conquista do cume de uma montanha, pico de uma trajetória marcada pelas oscilações entre autonomia e expressão da nacionalidade, atualização poética e reprodução indiscriminada de modismos estrangeiros, acusação que Veríssimo lança sobretudo aos coetâneos, dopados pela "petulância intelectual", "a improvisação e invencionice, a leviandade em aceitar inspirações desencontradas e a facilidade de entusiasmos irrefletidos por novidades estéticas, filosóficas ou literárias" 68 Machado de Assis é o avesso desse pendor, expressão de excelência, mas pela mesma razão figura única e solitária.

A História de J osé Veríssimo conclui de modo paradoxal: de um lado, apresenta a obra do maior escritor brasileiro, sugerindo que o percurso histórico coincide com uma linha ascensional que desemboca no presente, colocado acima de todos os demais períodos, graças ao aparecimento do expoente máximo da arte nacional; de outro, a obra de M achado não corresponde ao corolário individual de

\footnotetext{
Idem, p. 14.

Idem, p. 304.

Idem, p. 12.
} 
uma propensão coletiva, e sim o inverso - e, nesse aspecto, o crítico irmana-se ao ficcionista - daquilo que se verifica na época. O grupo encaminha-se para um lado, Machado e Veríssimo para outro, configurando o isolamento de ambos, especialmente o do segundo, após a morte do primeiro, em 1908.

Por razões diversas, e até opostas, Romero e Veríssimo, entre 1888 e 1916, estão desencantados com o presente: um denunciou o atraso e a ignorância vigentes; o outro expressou desalento diante da atualidade. Com isso, contradisseram um tique da historiografia literária, depois restaurada pelos modernistas: a de que a narração das fases do trajeto culmine na elevação do hoje, exaltado enquanto auge de um processo, de que ele é efeito e síntese. Os dois historiadores visualizaram no contemporâneo a ruína e o fracasso, embora fossem eles, sobretudo R omero, fruto desse tempo e de idéias evolucionistas. Por seu turno, a futura historiografia literária acolheu os dois diagnósticos: tanto o que narrava a trajetória cronológica, quanto o que atribuía ao período em que atuaram o juízo de decadente e desestimulante. Só que enxertou ao sintoma verificado o remédio, enxergando a si mesmo e à sua época como salvação, de modo que a historiografia da literatura brasileira produzida após o M odernismo resgatou o pendor do gênero e, outra vez, o presente apareceu como o ponto supremo da historia, resultado da evolução continua na direção do progresso. Da sua parte, Romero e Veríssimo permaneceram presos ao diagnóstico formulado, que os englobou e fixou no passado, fotografia muda de uma época carente de revitalização. 
